\title{
PEMEROLEHAN KATA ANAK PADA USIA 3,0-5,0 TAHUN
}

\author{
Afnita \\ athailah.afif@yahoo.co.id \\ Universitas Negeri Padang
}

\begin{abstract}
Penelitian ini bertujuan untuk mendeskripsikan pemerolehan kategori kata yang telah diperoleh anak usia 3;0-5;0 tahun di PAUD Bakti Bunda Tabing Padang. Jenis penelitian ini adalah penelitian kualitatif, yaitu penelitian yang bertujuan untuk menggambarkan dan menjelaskan pemerolehan kategori kata apa saja yang telah diperoleh anak usia 3;0-5;0 tahun. Teknik yang digunakan dalam pengumpulan data adalah teknik rekam, catat, dan wawancara. Berdasarkan temuan penelitian dan pembahasan yang telah dilakukan, dapat disimpulkan bahwa anak usia 3;0-5;0 tahun telah mampu menggunakan verba, ajektiva, nomina, pronomina, numeralia, adverbia, dan kata tugas, baik dalam bentuk dasar maupun turunan.
\end{abstract}

Kata kunci: Pemerolehan, kata, anak usia 3,0-5,0 tahun

\section{PENDAHULUAN}

Anak yang lahir ke dunia telah memiliki kemampuan dan kapasitas untuk berbahasa. Bahasa diperoleh anak melalui proses alamiah, melalui komunikasi seharihari bukan melalui pembelajaran yang membutuhkan guru, tempat, dan waktu yang khusus. Subyakto (1988) menyatakan bahwa pemerolehan bahasa pertama terjadi apabila anak belum pernah belajar bahasa apapun. Sehubungan dengan pemerolehan bahasa pertama anak, ada faktor yang mempengaruhi, yaitu perkembangan kognitif anak, perkembangan sosial anak, alat pemerolehan bahasa yang dibawa sejak lahir, dan urutan pemerolehan bahasa anak.

Selanjutnya, Dardjowidjoyo (2003) menyatakan bahwa pemerolehan bahasa atau language acquisition adalah proses penguasaan bahasa yang dilakukan oleh anak secara natural. Pemerolehan bahasa yang terjadi pada anak melalui dua proses, yaitu proses kompetensi atau kemampuan dan proses perfomansi, termasuk di dalamnya proses pemahaman dan proses penerbitan atau proses menghasilkan kalimat. Dalam hal pemerolehan bahasa, proses kompetensi dianggap sebagai proses yang pertama yang dilalui oleh seorang anak, baru setelah itu anak melalui proses performansi.

Sejalan dengan itu, Chaer (2003) juga menyatakan bahwa pada pemerolehan bahasa pertama, anak mengalami dua proses yaitu proses kompetensi dan proses performansi. Proses kompetensi merupakan proses penguasaan tatabahasa yang berlangsung secara tidak sengaja. Proses kompetensi ini menjadi syarat untuk terjadinya proses performansi, yang terdiri atas dua proses yaitu proses pemahaman yang melibatkan kemampuan atau kepandaian mengamati atau kemampuan mempersepsi kalimat-kalimat yang didengar, dan proses yang kedua yaitu proses penerbitan atau proses menghasilkan kalimat.

Pada awal pemerolehan bahasa, seorang anak akan lebih banyak mendengarkan atau menyimak. Kemudian, anak akan berusaha untuk menirukan kata-kata yang 
pernah didengarnya, baik dari orang tuanya, keluarga, maupun lingkungan sekitarnya. Dengan demikian, kemampuan berbahasa pertama yang dikuasai oleh anak adalah mendengar atau menyimak. Selanjutnya, anak akan menguraikan kata-kata tersebut dan mengujarkannya kembali melalui kata-kata.

Pada kenyataannya, semua anak akan menguasai bahasa ibunya terlebih dahulu. Pada saat memperoleh bahasa ibunya, kemampuan anak akan berkembang dengan pesat. Anak pada akhirnya akan mampu berbicara sebagaimana orang dewasa berbicara melalui komunikasi sehari-hari tanpa adanya pembelajaran. Pemerolehan bahasa yang dimilikinya baik dalam bentuk kelas kata verba, adjektiva, adverbial, nomina, pronomina, dan numeralia, merupakan kata-kata yang direkamnya dari lingkungan, terutama lingkungan keluarga. Hal ini menunjukkan bahwa keluarga menjadi faktor terpenting dalam terbentuknya kemampuan berbahasa anak.

Kosakata merupakan perbendaharaan kata-kata dalam suatu bahasa. Menurut Bloomfield (dalam Tarigan, 2009), kata adalah bentuk bebas yang paling kecil yaitu kesatuan terkecil yang dapat diucapkan secara mandiri. Kata terdiri atas beberapa kelas/kategori. Alwi, dkk. (2003) membagi kelas kata menjadi 7 di antaranya: (1) verba, (2) adjektiva, (3) adverbia, (4) nomina, (5) pronomina, (6) numeralia, dan (7) kata tugas. Penelitian ini dilakukan untuk mengkaji kategori kata anak usia dini di PAUD Bakti Bunda Tabing Padang.

Berdasarkan pengamatan awal di PAUD Bakti Bunda Tabing Padang terhadap kemampuan anak usia 3,0-5,0 tahun dalam bertutur juga telah mampu berkomunikasi dengan teman dan guru mereka. Dalam berkomunikasi, mereka telah menggunakan banyak jenis kata. Beberapa orang di antara mereka ada yang mampu berkomunikasi, namun tidak menyatakan secara tepat acuan dari tuturan mereka. Misalnya, untuk menyatakan benda itu globe, mereka menyebutnya bola kaki. Bahasa pada anak-anak terkadang sukar diterjemahkan, karena anak pada umumnya masih menggunakan struktur bahasa yang masih kacau dan masih mengalami transisi dalam berbicara sehingga sukar dipahami oleh mitra tuturnya. Selain itu, anak-anak juga masih memiliki keterbatasan dalam kosakata (leksikon) dan dalam pelafalan fonemnya secara tepat.

Pemerolehan kata pada anak akan beragam sesuai dengan pemahaman dan kemampuan penelaahan anak-anak tersebut. Penelitian ini dilakukan untuk mendeskripsikan kata apa saja yang telah diperoleh oleh anak usia 3,0-5,0 tahun di PAUD Bakti Bunda Tabing Padang.

\section{METODE}

Jenis penelitian ini adalah penelitian kualitatif. Moleong (2005) menyatakan bahwa penelitian kualitatif adalah penelitian yang bermaksud untuk memahami fenomena tentang apa yang dialami oleh subjek penelitian misalnya perilaku, motivasi, tindakan dan lain-lain, dan dengan cara deskripsi dalam bentuk kata-kata dan bahasa, pada suatu konteks khusus yang alamiah dan dengan memanfaatkan berbagai metode alamiah. Peneliti mengambil metode ini karena data-data yang dikumpulkan berupa kata-kata yang diperoleh berupa ujaran anak. Penelitian ini menggunakan metode deskriptif dengan tujuan menggambarkan dan menjelaskan pemerolehan kata anak usia $(3,0-5 ; 0)$ tahun pada PAUD Bakti Bunda Tabing Padang. 
Teknik yang digunakan dalam pengumpulan data adalah teknik rekam, catat, dan wawancara.

\section{HASIL DAN PEMBAHASAN}

Berdasarkan temuan penelitian, diketahui anak usia 3,0-5,0 tahun di PAUD Bakti Bunda Tabing telah memperoleh dan menggunakan 7 kategori kata, yaitu verba, ajektiva, adverbial, nomina, pronomina, numeralia, dan kata tugas. Anak PAUD Bakti Bunda Tabing Padang paling banyak memperoleh kategori kata nomina. Hal ini disebabkan anak selalu dapat merujuk nomina tersebut, sedangkan kategori kata yang lain tidak dapat dirujuknya atau divisualisasikannya. Anak akan cenderung lebih cepat memperoleh sesuatu yang wujudnya nyata daripada yang abstrak. Oleh karena itu, anak lebih banyak memperoleh kategori nomina. Hal ini sesuai dengan pendapat Dardjowidjojo (2000) yang menyatakan bentuk leksikal yang awal dikuasai anak adalah kata-kata megenai benda, gambar, dan mainan.

Anak lebih cenderung menggunakan jenis nomina dasar daripada nomina turunan. Hal ini dikarenakan anak yang berada dalam masa pertumbuhan cenderung mudah untuk memperoleh dan memahami sesuatu yang sederhana dibandingkan sesuatu yang kompleks. Hal ini sesuai juga dengan pendapat Maksan (1993) yang menyatakan bahwa anak-anak memperoleh pengertian tidaklah secara serentak, tetapi sesuai urutan kesukarannya. Anak cenderung memperoleh yang mudah terlebih dahulu dibandingkan sesuatu yang sukar. Beberapa nomina turunan yang telah digunakan anak dalam berkomunikasi adalah nomina turunan dengan prefiks pe-, sufiks - nya dan -an, serta konfiks ke-an. Selain itu, anak juga telah menggunakan nomina turunan dengan reduplikasi.

Selain telah memperoleh kategori nomina, anak PAUD Bakti Bunda Tabing Padang juga telah memperoleh kategori verba. Anak telah menggunakan verba sebagaimana penggunaan verba oleh orang dewasa. Penggunaan jenis verba yang diucapkan anak sudah tepat. Anak mengucapkan kata sesuai dengan maksud yang ingin disampaikannya. Hal ini sesuai dengan pendapat Clark (2002) yang mengemukakan bahwa anak yang berusia 4-5 tahun sudah mampu menggunakan kata sesuai dengan penggunaan kata oleh orang dewasa.

Anak PAUD Bakti Bunda Tabing Padang lebih banyak menggunakan verba dasar. Hal ini disebabkan anak yang seyogianya merupakan pribadi yang sedang berada dalam masa pertumbuhan lebih cepat menguasai sesuatu yang sederhana daripada yang kompleks. Anak cenderung memperoleh yang mudah terlebih dahulu dibandingkan sesuatu yang sukar. Selain verba dasar, anak juga telah memperoleh verba turunan. Jumlah verba turunan yang ditemukan tidaklah sebanyak verba dasar. Verba turunan yang diperoleh responden penelitian berupa verba turunan yang diperoleh melalui proses afiksasi dan reduplikasi. Verba turunan yang diperoleh responden melalui proses afiksasi di antaranya adalah verba turunan yang menggunakan prefiks $d i$-, ber-, me-, dan ter-. Anak juga telah menggunakan verba turunan dengan sufiks -kan dan konfiks me-kan.

Selanjutnya, anak juga sudah mampu menggunakan ajektiva untuk mengungkapkan apa yang ada dalam pikirannya. Ajektiva yang digunakan hanya ajektiva dasar dan belum ada responden yang menggunakan ajektiva turunan. Anak 
memperoleh bahasa secara bertahap, sedikit demi sedikit, tidak langsung mampu berutur sebagaimana orang dewasa.

Dalam berkomunikasi sesama teman maupun gurunya, anak juga telah menggunakan pronominal, namun jumlahnya tidak begitu banyak. Hal ini disebabkan anak lebih cepat memahami dan menggunakan kata-kata utama seperti nomina, verba, dan ajektiva, karena ketiga kategori kata tersebut lebih mudah dirujuk dibandingkan kategori kata lain.

Hasil penelitian juga menunjukan bahwa anak usia 3,0-5,0 tahun di PAUD Bakti Bunda Tabing Padang telah mampu memahami dan menggunakan kata numeralia sebagaimana mestinya. Jumlah numeralia yang dikuasai oleh anak tidaklah begitu banyak karena numeralia yang dikuasai oleh anak hanya berupa numeralia dasar. Hal ini dikarenakan anak lebih cenderung memahami dan memperoleh sesuatu yang sederhana daripada sesuatu yang kompleks.

Begitu juga dengan kelas kata adverbia, Anak telah mampu memahami dan menggunakan adverbia sebagaimana orang dewasa. Adverbia yang diperoleh anak di PAUD Bakti Bunda Tabing Padang berupa adverbia dasar. Sementara itu, untuk kata tugas, anak hanya baru menggunakan kata tugas yang berbentuk preposisi. Kata tugas lain belum ditemukan pada ujaran responden penelitian. Hal ini juga disebabkan karena anak memperoleh bahasa secara bertahap, mulai dari yang mudah, bukan serta merta.

\section{SIMPULAN, IMPLIKASI, DAN SARAN}

Berdasarkan temuan penelitian dan pembahasan yang telah dilakukan, dapat disimpulkan bahwa anak usia 3,0-5,0 di PAUD Bakti Bunda Tabing Padang telah mampu menggunakan verba, ajektiva, nomina, pronomina, numeralia, adverbia, dan kata tugas, baik bentuk dasar maupun turunan. Dalam hal ini, anak lebih banyak dan lebih cepat menguasai bentuk dasar daripada bentuk turunan. Hal ini disebabkan karena anak cenderung memperoleh hal yang mudah terlebih dahulu dibandingkan sesuatu yang sukar.

Jika pada penelitian ini disimpulkan bahwa anak lebih banyak dan lebih cepat menguasai bentuk dasar daripada bentuk turunan, maka pada pembelajaran Bahasa Indonesia yang diberikan kepada siswa yang berada pada kelas rendah juga akan lebih cepat menguasai kosakata yang sederhana. Oleh karena itu, pembelajaran bahasa Indonesia di sekolah harus disusun berdasarkan tingkat kesukarannya. Pelajaran disusun dari materi yang sederhana, kemudian bertambah sulit, dan semakin sulit.

Beberapa saran penulis orang tua, sebaiknya anak diituksertakan pada proses komunikasi agar anak mampu berkomunikasi sebagaimana orang dewasa pada umumnya, (2) guru PAUD hendaknya membiasakan menggunakan bahasa Indonesia kepada anak usia 2,6-5,0 tahun berdasarkan tingkat kesukarannya, dimulai dari yang mudah, agak sulit, dan makin sulit. 


\section{REFERENSI}

Agus Sujanto. 1996. Psikologi Perkembangan. Jakarta: Rineka Cipta.

Alwi, Hasan dkk. 2003. Tata Bahasa Baku Bahasa Indonesia. Jakarta: Balai Pustaka.

Arifin, Zainal dan Junaiyah. 2009. Morfologi: Bentuk Makna dan Fungsi. Jakarta: Gramedia.

Chaer, Abdul. 2003. Psikolinguistik Kajian Teoretik. Jakarta: PT Rineka Cipta.

Dardjowijdjojo, Soenjono. 2000. Echa: Kisah Pemerolehan Bahasa Anak Indonesia. Jakarta: Grasindo.

Dardjowijdjojo. Soenjono. 2003. Psikolinguistik: Pengantar Pemahaman Bahasa Manusia. Jakarta: Unika Atma Jaya.

Mahsun. 2006. Metode Penelitian Bahasa: Tahapan, Startegi, Metode, dan Tekniknya. Jakarta: Raja Grafindo Persada.

Maksan, Marjusman. 1993. Psikolinguistik. Padang: IKIP Padang Press.

Moleong, Lexy J. 2009. Metodologi Penelitian Kualitatif. Bandung: Remaja Rosdakarya

Samarin, William J. 1988. Ilmu Bahasa Lapangan. Yogyakarta: Kanisius.

Subyakto-N, Sri Utari. 1988. Psikolinguistik: Suatu Pengantar. Jakarta: Departemen Pendidikan dan Kebudayaan Direktoral Jendral Pendidikan Tinggi Proyek Pengembangan Lembaga Pendidikan Tenaga Kependidikan.

Tarigan, Henry Guntur. 2009. Pengajaran Morfologi. Bandung: Angkasa.

Tarigan, Henry Guntur. 2011. Pengajaran Kosakata. Bandung: Angkasa. 